Volume 2 Nomor 2, 2017, hlm 1-9

ISSN: 2502-079X (Print)

ISSN: 2503-1619 (Electronic)

Info Artikel:

Diterima: $18 / 04 / 2017$

Direvisi: 20/07/2018

Dipublikasikan: 30/07/2017

Dipublikasikan oleh :
Indonesian Institute for Counseling, Education and Therapy (IICET)

Akses Online : http://jurnal.iicet.org/index.php/jrti

\title{
TAMPILAN PERILAKU ANTI SOSIAL PADA SISWA SEKOLAH DASAR Elsa gustia
}

\section{Abstratc}

Anti-social behavior is a negative behavior or behavior deviating from the norms, whether the rules of family, school, and society. Types of anti-social behavior in one of them is aggressive behavior, negativism and behavior control. People who have anti-social behavior usually prefer to be alone rather than gathering with the crowd. Risk factors that cause anti-social behavior in a person can be categorized as personal factors, family, as well as related to school and sosial.Upaya child and anti-social handling can be done with the efforts of parents apply authoritative parenting. While the teacher can be attempted to handle anti-social children by applying cooperative learning methods as well as providing psychological attention and the development of multiple intelligence of children.

Keyword: Anti-social.

This is an open access article distributed under the Creative Commons
Attribution License, which permits unrestricted use, distribution, and
reproduction in any medium, provided the original work is properly cited. (C2017 by author

\section{PENDAHULUAN}

Menurut kamus psikologi Chaplin.J.P (2011: 11) penyesuaian berasal dari adjustment diartikan dengan dua makna yaitu: variasi dalam kegiatan organism untuk mengatasi suatu hambatan dan memuaskan kebutuhan-kebutuhannya, dan menekankan hubungan yang harmonis dengan lingkungan fisik dan sosial. Gerungan (2004: 55) menjelaskan penyesuaian diri berarti "mengubah diri sesuai dengan keadaan lingkungan, tetapi juga mengubah lingkungan sesuai dengan (keadaan) keinginan diri”. Senada dengan itu Firman (1992: 19) mengemukakan bahwa :

"penyesuaian diri adalah kemampuan seseorang untuk bereaksi terhadap kenyataankenyataan, situasi-situasi dan hubungan sosial dalam lingkungan guna memenuhi kebutuhankebutuhan hidupnya sesuai dengan norma-norma yang berlaku. Individu yang mampu menyesuaikandiri akan siap menghadapi situasi baru sesuai dengan norma yang berlaku di lingkungan tersebut." 
Menilik pengertian penyesuaian diri di atas didapat bahwa setiap individu harus mampu menghadapi lingkungan atau situasi yang berbeda dengan beberapa cara, salah satunya yaitu menyesuaikan diri dengan keinginan diri pribadi (Zola, Ilyas, \& Yusri, 2017; Reski, Taufik, \& Ifdil, 2017; Ifdil, 2010). Seperti yang diungkapkan oleh James dan Joan (1995: 15) bahwa penyesuaian diri adalah interaksi individu yang kontinu dengan dirinya sendiri, orang lain, dan dunia.Syamsu Yusuf LN (2004: 24) menjelaskan bahwa "Siswa sekolah dasar pada umumnya berusia 6 sampai 13". Ada tiga ciri yang menonjol pada masa ini yaitu: dorongan yang besar untuk berhubungan dengan kelompok sebaya, dorongan ingin tahu tentang dunia sekitarnya, dan perkembangan fisik.Pendapat diperjelas Muhibbin Syah (1995: 46) menjelaskan bahwa "masa anak-anak (late childhoold) berlangsung antara usia 6 sampai 12 tahun dengan ciri-ciri utama memiliki dorongan untuk keluar dari rumah dan memasuki kelompok sebaya (peer group)".

Berdasarkan pendapat para ahli diatas dapat disimpulkan bahwa masa sekolah dasar dengan rentang usia antara 6-13 tahun memiliki ciri utama adanya dorongan yang besar untu berhubungan dengan kelompok sebaya, danya dorongan ingin tahu tentang dunia disekitarnya, serta adanya perkembangan fisik. Menyangkut dorongan yang besar untukberhubungan dengan kelompok sebaya, anak cendrung keluar rumah dalam hal bersosialisasi. Anak akan merasa nyaman bila mereka dapat diterima dalam satu kelompok dengan temn-teman sebayanya, dan sebaliknya anak akan merasa tidak nyaman bila tidak bisa diterima dalam kelompoknya.

Pernyataan sependapat dengan para ahli diatas adalah pendapat Elizabeth B. Hurlock (2001: 155-156) yang menyatakan bahwa: Akhir masa kanak-kanak sering disebut sebagai "usia berkelompok" karena ditandai dengan adanya minat terhadap aktivitas teman-teman dan menigkatnya keinginan yng kuat untuk diterima sebagai anggota suatu kelompok, dan merasa tidak puas bila tidak bersama teman-temannya. Anak tidak lagi puas bermain sendiri di rumah atau dengan anggota-anggota keluarga. Anak ingin bersama dengan teman-temannya dan akan merasa kesepian serta tidak puas bila tidak bersama teman-temannya.

Mengacu pada masalah di atas Elizabeth B. Hurlock (2001: 155-156) berbendapat "siswa bersekolah dasar senang bergaul dan membentuk kelompok-kelompok dengan teman sebayanya". Sebagaimana telah dipaparkan diatas secara teoritis bahwa anak sekolah dasar mulai suka bersosialisasi dengan teman sebayanya.

Masalah akan timbul apabila dalam berinteraksi atau bersosialisasi anak menujukan perilaku yang negatif atau anti sosial terhadap kelompoknya, seperti anak yang masa bodoh dengan temannya, suka melakukan perkelahian. Burt, Donnellan, Iacono \& McGue (2011: 634) berpendapat bahwa perilaku anti sosial adalah sebagai perilaku-perilaku yang menyimpang dari norma-norma, baik aturan keluarga, sekolah, masyarakat, maupun hukum. Pendapat ini lebih eksteem, karena bukan sekedar permasalahan tentang perilaku yang mencakup perkembangan sosial, emosi, dan moral dan berdampak pada perilaku negatif, namun sudah pada pelanggaran hukum yang berlaku di negara Indonesia.

Keadaan demikian pada kenyataannya belum mendapat perhatian dan penanganan yang optimal oleh pihak sekolah, sehingga anak dengan perilaku anti sosial bisa menjadi anak yang terisolir, dan tidak diterima teman-teman di dalam kelompoknya, dalam perkembangan anak anti sosial akan mengalami hambatan dlam bersosialisasi, lebih jauh masa depan yang kurang baik kaeana anak dengan perbuatan melaggar hukum. Kenyataan ini menarik perhatian untuk dikaji dan dianalisa sehingga memperoleh gambaran realitas secara jelas tentang perilaku anti sosail pada anak sekolah dasar.

Djaali (2000: 185) menjelaskan konsep diri berkembang dari pengalaman seseorang tentang berbagai hal mengenai dirinya sejak ia kecil, terutama yang berkaitan dengan perlakuan dari orang lain terhadap dirinya.Melalui perlakuan yang berulang-ulang dan setelahmenghadapi sikap-sikap tertentu dari orang lain di lingkungan kehidupannya maka akan berkembanganlah konsep diri seseorang.

\section{PEMBAHASAN}

\section{Pengertian perilaku anti sosial}

Antisosial terdiri dari kata anti dan sosial, anti yang berarti menentang atau memusuhi dan sosial yang berarti berkenaan dengan masyarakat. Jadi, antisosial adalah suatu sikap yang 
melawan kebiasaan masyarakat dan kepentingan umum. Sikap antisosial memiliki definisi longgar, namun sebagian besar setuju dengan ciri-ciri perilaku antisosial yang dikenal umum, seperti mabuk-mabukan di tempat umum, vandalisme, mengebut di jalan raya, dan perilaku yang dianggap menyimpang lainnya. Secara sederhana, perilaku antisosial bisa digambarkan sebagai "perilaku yang tidak diinginkan sebagai akibat dari gangguan kepribadian dan merupakan lawan dari perilaku prososial" (Lane 1987; Farrington 1995; Millon et al 1998 dalam Setiyawati, 2010).

Menurut Nevid dkk. (2005: 277) gangguan perilaku antisosial adalah sebuah gangguan perilaku yang ditandai oleh perilaku antisosial dan tidak bertanggungjawab serta kurangnya penyesalan untuk kesalahan mereka. Sedangkan menurut Cleckley (1976 dalam Silitonga, 2010) Orang dengan gangguan kepribadian antisosial (antisocial personality disorder) secara persisten melakukan pelanggaran terhadap hak-hak orang lain dan sering melanggar hukum. Mereka mengabaikannorma dan konvensi sosial, impulsif, serta gagal dalam membina hubungan interpersonal dan pekerjaan. Meski demikian mereka sering menunjukkan kharisma dalam penampilan luar mereka dan paling tidak memiliki intelegensi rata-rata.Menurut Oxford psychology, anti sosial adalah perilaku yang merugikan orang lain merugikan masyarakat. Perilaku anti sosial terdiri dari banyak bentuk. Salah satu contohnya bermusuhan (yang berarti emosional, impulsif dan didorong oleh rasa sakit atau tertekan) dengan menanggapi situasi secara langsung; atau dapat berperilaku anti sosial dengan perencanaan yang disengaja dari waktu ke waktu. Dua jenis perilaku anti sosial yang sangat berbahaya bagi individu dan masyarakat yaitu agresi dan prasangka.

Pendapat senada dijelaskan Kathleen Stassen Barger (2003: 302),Perilaku anti sosial sering dipandang sebagai sikap dan perilaku yang tidak mempertimbangkan penilaian dan keberadaan orang lain ataupun masyarakat secara umum disekitrnya. Tindakan-tindakan anti sosial ini sering kali mendatangkan kerugian bagi masyarakat luas sebab pada dasarnya si pelaku tidak menyukai keteraturan sosial (social order) yang diinginkan oleh sebagian besar anggota masyarakat lain.

Pendapat diatas dipertegas Burt, Donnellan, Iacono \& McGue (2011: 634) berpendapat bahwa perilaku anti sosial adalah sebagai perilaku-perilaku yang menyimpang dari norma-norma, baik aturan keluarga, sekolah, masyarakat, maupun hukum. Dari ketiga pendapat diatas dapat ditarik kesimpulan bahwa perilaku anti sosial adalah perilaku yang menyimpang dari norma-norma, baik aturan keluarga, sekolah,masyarakat, maupun hukum, karena sipelaku tidak menyukai keteraturan sosial (social order) oleh karenanya dalam berperilaku tidak mempertimbangkan penilaian dan keberadaan orang lain ataupun masyarakat secara umum di sekitarnya sehingga mendatangkan kerugian bagi masyarakat.

\section{Jenis perilaku anti sosial pada anak sekolah dasar}

Menurut Wiramihardja (2012: 111) terdapat beberapa jenis perilaku anti sosial, yaitu, Perilaku terbuka (overt) dan perilaku tertutup (covert). Perilaku terbuka ini ditampilkan oleh otot maupun kerangka badan seperti berjalan, memukul dan lain-lain. Perilaku tertutup adalah perilaku yang geak-geriknya tidak langsung menyatakan maksudnya seperti marah yang di perlihatkan dengan muka merah atau perilaku non-agresif seperti perilaku melanggar peraturan dengan berbohong. Pendapat lain tentang jenis perilaku anti sosial adalah anak yang tidak patuh. Menurut Schaefer dan Millman (1981: 235), ada 3 karakteristik anak anti sosial khususnya pada anak yang tidak patuh, yaitu :

1. The Passive Resistant Type, yaitu anak menjadi diam atau menghindari perintah dengan cara pasif, mengikuti perintah tetapi dengan setengah hati.

2. The Openly Defiant Type, yaitu anak secara langsung menolak perintah secara verbal.

3. The Spiteful Type of Noncompliance, yaitu anak melakukan hal yang sebaliknya dari yang diperintahkan.

T. Sutjihati Somantri (2006: 43-45) menjelaskan bahwa bentuk tingkah laku sosial yang dijumpai pada masa anak-anak dilandasi oleh pola tingkah laku yang terbentuk pada masa bayi, tetapi beberapa diantaranya merupakan bentuk tingkah laku yang tidak sosial bahkan anti sosial yang sering dijumpai pada masa anak-anak adalah : 
a. Negativisme, Tingkah laku menguasai negativisme adalah merupakan gabungan antara keyakinan diri, perlindungan diri, dan penolakan yang berlebihan. Negativisme merupakan akibat situasi sosial, misalnya disiplin yang terlalu keras atau sikap orang dewasa yang tidak toleran. (Alex Sobur 2003: 196)

b. Agresi, Agresi merupakan tindakan nyata yang mengancam sebagai ungkapan rasa benci. Anak akan menunjukan kecenderungan untuk mengulangi tindakan agresinya bila tindakan tersebut memberikan hasil yang menyenangkan bagi dirinya, terutama menghadapi frustasi atau kecemasan yang dirasanya (Alex Sobur 2003: 208). Beberapa penyebab munculnya agresi pada anak-anak antara lain frustasi, keinginan untuk menarik perhatian, kebutuhan akan perlindungan karena rasa tidak aman, dan identifikasi dengan orangtua yang agresif. Menurut Calhoun dan Acocella (1990: 354) "Agressiceness is the exercise of your own rights in ways that violate other peoples's rights".

Sikap agresif adalahpenggunaan hak sendiri dengan cara melanggar hak orang lain. MenurutBerkowitz 1993 (dalam Alex Sobur 2003: 432) mendefenisikan agresi sebagai " segala bentuk perilaku yang dimaksudkan untuk menyakiti seseorang, baik secara fisik maupun mental”. Karena itu, secara sepintas setiap perilaku yang merugikan atau menimbulkan korban pada pihak orang lain dapat disebut sebagai perilaku agresif (Sarwono, 1997: 296). Ini dipertegas lagi oleh Baron (1997: 345) menurutnya, agresi adalah “ Tingkah laku individu yang ditunjukan untuk melukai atau mencelakakan individu lain yang tidak menginginkan datangnya tingkah laku tersebut". Defenisi agresi dari Baron mencangkup emapt faktor: tingkah laku, tujuan untuk melukai atau mencelakakan, individu yang menjadi pelaku, dan individu yang menjadi korban, serta ketidakinginan si korban menerima tingkah laku si pelaku.

Ragam antisosial dibawah ini, menggambarkan kombinasi gagasan yang diwariskan langsung oleh teori evolusi. (Millon dan Davis, 2000: 234) Lima Variasi Kepribadian Antisosial :

1. Anti sosial pencemburu (varian murni)

2. Anti sosial pengambil resiko (ciri histrionik)

3. Anti sosial penjaga reputasi (ciri marsisistik)

4. Anti sosial nomadis (cirri schizoid, avoidant)

5. Anti sosial pendengki (cirri sadistic, paranoid)

6. Tingkah laku menguasai diartikan sebagai tindakan untuk mencapai atau mempertahankan penguasaan suatu situasi sosial.

Bentuk tingkah laku anti sosial dapat membuat anak menarik diri dari lingkungan sosial dan pada akhirnyaanak tidak diterima dalam kelompok sebaya. Faktor-faktor penyebab perilaku anti sosial pada anak dapat dianalisa dari pendapat Lewin (dalam Walgito, 2003:16) memberikan formulasi mengenai perilaku prososial dan anti sosial itu dengan bentuk $B=f(E, O), B=$ Behavior, $\mathrm{f}=$ Fungsi, $\mathrm{E}=$ Environment, dan $\mathrm{O}=$ Organisme. Formulasi tersebut mempunyai makna bahwa perilaku (behavior) merupakan fungsi yang bergantung dengan lingkungan organisme.

Berdasarkan pernyataan diatas dapat disimpulkan bahwa perilaku prososial dan anti sosial anak dipengaruhi oleh lingkungan dan sosialisasi dengan orang-orang disekitar anak. Dari teori faktorfaktor penyebab perilaku anti sosial pada anak diatas selanjutnya diuraikan atau ditambahkan lagi oleh Fortin (2003: 682) bahwa faktor resiko yang menyebabkan perilaku anti sosial pada anakanak dapat dikategorikan sebagai faktor pribadi (personal risk factors), keluarga (family risk factors), berkaitan dengan sekolah (school-related risk factors) dan sosial (social risk factors).

Penelitian pada anak kembar membuktikan bahwa faktor genetik mempengaruhi perkembangan antisosial. Angka kriminalitas 2-3 kali lebih tinggi pada kembar monozigot dibandingkan kembar dizigot. (Gabbard, 2005).

Kemudian Schaefer dan William (1981) juga menjelaskan penyebab yang mendasari perilaku anti sosial yang ditimbulkan dari faktor resiko keluarga, diantaranya adalah:

1. Kurangnya disiplin, orangtua terlalu bersikap permisif dan sulit untuk mengatakan "tidak" pada anak.sehingga anak 'belajar' bahwa segal keinginannya pasti akan dituruti oleh orangtua. Hal ini membuat anak berani menolak hal-hal yang diperintahkan yang tidak disukainya, sikap anak keras, mau menang sendiri, dan sulit diatur. Bila dibiarkan dan berlarut-larut sifat anak seperti ini tidak hanya merugikanbagi dirinya sendiri tetapi sudah merugikan bagi orangtua bahkan orang lain disekitarnya. 
2. Pemberian disiplin yang sangat keras, orangtua menuntut anak untuk berlaku perfect (sempurna), mereka cenderung memaksa dan menginginkan disiplin 'instant' pada anak. Pemaksaan dan tuntutan yang berlebihan terhadap anak ini membuat anak melawan dan 'protes' dengan berperilakuyang sebaliknya. Pemberian disiplin yang tidak konsisten, kadang orangtua melarang kadang mereka membiarkan anak berlaku hal yang sama. Ketidakkonsistenan yang ditunjukan orangtua membuat anak bingung dan kemudian 'mencoba-coba' untuk menolak perintah orangtua, siapa tahu kali ini ia berhasil untuk tidak jadi melakukan hal yang diperintahkan.

3. Orangtua berada dalam setres atau konflik. Salah satu atau kedua orangtua menghindari peran pengasuhan anak dikarenakan kesibukan, ketidaktertarikan pada anak, masalah pribadi, atau adanya masalah dalam perkawinan. Hal ini juga mengakibatkan ketidak-konsistenan dan ketidakseragaman pengasuhan atau aturan yang diterapkan oleh kedua orangtua. Sehingga anak kembali menjadi bingung dan malah melawan.

Lebih lanjut Aankusuma (http://id.facebook.com) menjelaskan bahwa faktor-faktor yang mempengaruhi perkembangan sosial anak sekolah dasar kelas tinggi yang disebabkan faktor keluarga yakni status sosial ekonomi dalam keluarga. Kehidupan sosial banyak dipengaruhi oleh kondisi atau status kehidupan sosial keluarga dalam lingkungan masyarakat. Masyarakat akan memandang anak, bukan sebagai anak yang independen, akan tetapi dipandang dalam konteksnya yang utuh dalam keluarga anak itu, "ia anak siapa". Secara tidak langsung dalam pergaulan sosial anak, masyarakat dan kelompoknya akan mempertimbangkan norma yang berlaku didalam keluarganya. Perilaku anak akan banyak memperhatikan kondisi normatif yang telah ditanamkan oleh keluarganya. Sehubungan dengan hal itu, dalam kehidupan sosial anak akan senantiasa menjaga status sosial dan ekonmi keluarganya, dalam hal tertentu menjaga status sosial keluarganya itu mengakibatkan anak menempatkan dirinya dalam pergaulan sosial yang tidak tepat. Hal ini dapat berakibat lebih jauh, yaitu anak menjadi "terisolir"dari kelompoknya. Akibat lain mereka akan membentuk kelompok elit dengan normanya sendiri.

Pendapat diatas diperkuat oleh Supratiknya (2012: 86-89) yang berpendapat bahwa penyebab perilaku anti sosial adalah frustasi karena keluarga tidak rukun, penolakan sosial, orang tua kurang memberi bimbingan, dan pengaruh teman.

Sejalan dengan itu Sunarto dan B. Agung Hartono (1995: 130-133) menjelaskan bahwa perkembangan sosial manusia dipengaruhi oleh bebrapa faktor yaitu : keluarga, kematangan anak, status sosial, ekonomi keluarga, tingkat pendidikan, dan kemampuan mental terutama emosi dan inteligensi. Dari berbagai pendapat diatas dapat disimpulkan begitu pentingnya peran keluarga dimana merupakan lingkungan pertama yang memberikan pengaruh terhadap berbagai aspek perkembangan anak, termasuk perkembangan sosialnya. Kondisi dan tata cara kehidupan keluarga merupakan lingkungan yang kondusif bagi sosialiasi anak. Didalam keluarga berlaku normanorma kehidupan keluarga, dan dengan demikian pada dasarnya keluarga merekayasa perilaku kehidupan budaya anak.

Proses pendidikan yang bertujuan mengembangkan kepribadian anak lebih banyak ditentukan oleh keluarga. Pola pergaulan dan bagaimana norma dalam menempatkan diri terhadap lingkungan yang lebih luas ditetapkan dan diarahkan oleh keluarga. Sementara faktor-faktor pribadi (personal risk factors) dapat dianalisa dari pendapat Aankusuma (http://id.facebook.com) menjelaskan bahwa faktor-faktor yang mempengaruhi perkembangan sosial anak sekolah dasar kelas tinggi yaitu :

a) Faktor dari dalam (personal risk factors)

1) Kapasitas mental: emosi dan intelegensi.

Kemampuan berpikir mempengaruhi banyak hal, seperti kemampuan belajar, memecahkan masalah, dan berbahasa. Perkembangan emosi, berpengaruh sekali terhadap perkembangan sosial anak. Anak yang berkemampuan intelektual tinggi akan berkemampuan berbahasa baik. Oleh karena itu, kemampuan intelektual tinggi, kemampuan berbahasa baik, dan pengendalian emosi secara seimbang sangat menentukan keberhasilan dalam perkembangan sosial anak. Sikap saling pengertian memahami orang lain merupakan modal utama dalam kehidupan sosial dan hal ini akan dengan mudah dicapai oleh anak yang berkemampuan intelektualtinggi. Bersosialisasi memerlukan kematangan fisik dan psikis. Untuk mampu mempertimbangkan dalam proses sosial, memberi dan menerima pendapat 
orang lain, memerlukan kematagan intelektual lain, memerlukan kematangan intelektual dan emosi. Disamping itu kemampuan berbahasa ikut pula menentukan, dengan demikian untuk mampu bersosialisasi dengan baik diperlukan kematangan fisik sehingga setiap orang fisiknya telah mampu menjalankan fungsinya dengan baik.

2) Kesehatan anak

Anak-anak biasanya sulit untuk patuh bila mereka lelah,sakit, lapar, atau sedang ada tekanan emosional. Keadaan fisik yang tidak baik membuat seseorang tidak dapat berpikir positif. perasaan negatif lebih banyak muncul dan hal ini membuat anak tidak bersedia mematuhi hal yang diperintahkan (Taupik, dkk 2007: 153).

3) Jenis kelamin

Temuan Rodkin dkk. (2000: 22) menunjukan bahwa di sekolah dasar anak laki-laki lebih berperilaku anti sosial. Anak laki-laki lebih banyak membentuk geng kelas yang menonjol. Anak laki-laki pada umumnya cenderung sok berkuasa dan menganggap remeh pada anak perempuan.

4) Umur

Rodkin, dkk (2000: 24) Umur memengaruhi pembentukan sikap dan pola tingkah laku individu, makin bertambahnya umur diharapkan seseorang bertambah pula kedewasaannya, makin tepat dalam segala tindakannya. Kadang dijumpai ketidak sesuaian sikap yang dilakukan oleh anak sekolah dasar, sikapnya seperti anak kecil, manja, mintak dituruti segala keinginannya.

5) Kedudukan dalam keluarga

Keluarga yang terdiri atas beberapa anak, sering kali anak tertua merasa dirinya paling berkuasa dibandingkan dengan anak kedua atau ketiga. Anak bungsu mempunyai sifat ingin dimanjakan oleh kakak-kakaknya ataupun orangtuanya.Olehkarena itu, susunan atau urutan kelahiran terkadang akan meninmbulkan pola tingkah laku, peranan dan fungsi yang berbeda dalam keluarga.

b) School-Rlated Risk Factors

Dalam dunia pendidikan khususnya dalam dunia persekolahan merupakan proses sosialisasi anak yang seharusnya terarah pada prakteknya tidaklah berjalan baik. Meskipun hakikat pendidikan sebagai proses pengoperasian ilmu yang normati, yang akan memberikan warna kehidupan sosial anak didalam masyarakat dan kehidupan mereka dimasa yang akan datang, namun terkadang tidaklah mencapai tujuan yang optimal, karena pendidikan di sekolah saja tidak cukup. Pendidikan dalam arti luas harus diartikan bahwa perkembangan anak dipengaruhi oleh kehidupan keluarga, masyarakat, dan kelembagaan. Penanaman norma perilaku yang benar secara sengaja seharusnya diberikan kepada anak yang belajar di kelembagaan pendidikan tau sekolah.

c) Faktor Sosial (Social Risk Factors)

Peran masyarakat pertumbuhan dan perkembangan kehidupan anak dari lingkungan keluarga akhirnya berkembang ke dalam lingkungan masyarakat yang lebih luas. Ketidak mampuan keluarga memenuhi kebutuhan rohaniah anak mengakibatkan anak mencari kebutuhan tersebutke luar rumah. Ini merupakan awal dari sebuah petaka masa depan individu, jika di luar rumah anak menemukan sesuatu yang menyimpang dari nilai dan norma sosial. Pola kehidupan masyarakat tertentu kadang tanpa disadari oleh para warganya ternyata menyimpang dari nilai dan norma sosial yang berlaku di masyarkat umum, misalnya masyarakat yang suka berjudi. Itulah yang disebut sebagai sub kebudayaan menyimpang, misalnya masyarakat yang sebagian besar wargaya hidup mengandalkan dari usaha prostitusi, maka anak-anak di dalamnya akan menganggap sebagai bagian dari profesi yang wajar. Demikian pula anak yang tumbuh dan berkembang dilingkungan masyarakat penjudi atau peminum minuman keras, maka akan membentuk sikap dan pola perilaku menyimpang.

1) Pergaulan dengan anak lain.

Pola tingkah laku anak tidak bisa terlepas dari pola tingkah laku anak-anak lain di sekitarnya (Sarwono 2012: 268). Anak-anak lain yang menjadi teman pergaulannya sering kali memengaruhi kepribadian individu, dari teman bergaul tersebut anak akan menerima norma-norma atau nilai-nilai sosial yang ada dalam masyarakat. Apabila teman bergaulnya baik, anak akan menerima konsep-konsep norma yang bersifat positif, namun apabila teman 
bergaulnya kurang baik, anak sering kali akan mengikuti konsep-konsep yang yang bersifat negatif. Akibatnya terjadi pola tingkah laku yang menyimpang pada diri anak tersebut, olehkarena itu menjaga pergaulan dan memilih lingkungan pergaulan dan memilih lingkungan pergaulan yang baik sangat penting.

2) Media massa

Berbagai tayangan ditelevisi tentang tidak kekerasan, film-film yang berbau pornografi, sinetron yang berisi kehidupan bebas dapat memengaruhi perkembangan perilaku individu. Anak-anak yang belum mempunyai konsep yang benar tentang norma-norma dan nilai-nilai sosial dalam masyarakat, sering kali menerima mentah-mentah semua tayangan-tayangan negatif yang ditiru mengakibatkan perilaku sosial negative atau menyimpang. Dampak perilaku anti sosial jika dibiarkan akan berpengaruh buruk terhadap kehidupan psikologis serta kehidupan sosial anak, maka sangat penting adanya upaya pemecahan penanganan perilaku anti sosial khususnya pada anak dengan perilaku anti sosial di sekolah dasar.

Ciri-ciri diagnostik dari gangguan kepribadian antisosial menurut Nevid (2005: 279) adalah:

a. Paling tidak berusia 18 tahun.

b. Ada bukti gangguan perilaku sebelum usia 15 tahun, ditunjukkan dengan perilaku seperti membolos, kabur, memulai perkelahian fisik, menggunakan senjata, memaksa seseorang untuk melakukan aktivitas seksual, kekejaman fisik pada orang maupun binatang, merusak atau membakar bangunan secara sengaja,berbohong, mencuri, atau merampok.

c. Sejak usia 15 tahun menunjukkan kepribadian yang kurang kepedulian yang kurang dan pelanggaran terhadap hak-hak orang lain.

\section{SIMPULAN}

1. Pengertian perilaku anti sosial

Menurut Burt, Donnellan, Iacono \& McGue (2011: 634) berpendapat bahwa perilaku anti sosial adalah sebagai perilaku-perilaku yang menyimpang dari norma-norma, baik aturan keluarga, sekolah, masyarakat, maupun hokum.

2. Bentuk-bentuk perilaku anti sosial pada anak sekolah dasar yaitu :

a) Negativisme

b) Agresi

c) Tingkah laku menguasai

3. Faktor-faktor penyebab perilaku anti sosial

Menurut Fortin (2003: 682) bahwa faktor anti sosial pada anak adalah: faktor pribadi (personal risk factors), keluarga (family risk factors), berkaitan dengan sekolah (school-related risk factors) dan sosial (social risk factors).

4. Upaya pemecahan menangani perilaku anti sosial pada siswa sekolah dasar harus dilakukan oleh keluarga (orangtua), sekolah (guru dan kepala sekolah), dan masyarakat adalah: Orangtua atau keluarga mampu menerapkan pola asuh authoritative. Tidak memberikan disiplin yang sangat keras, tidak menuntut anak untuk berperilaku perfect (sempurna)., memberikan pola disiplin yang konsisten,memberikan suasana hidup dalam kasih sayang, memberikan teladan yang baik, memenuhi, mencukupi, serta menangani keadaan fisik dan mental anak dengan baik, mengajarkan anak untuk bersosialisasi dengan berbagai latar belakang status sosial dan ekonomi, menanamkan pemahaman bahwa dalam urutan anak dalam keluarga harus saling menyayangi dan memilki peranan sesuai dengan kemampuan anak serta harus mengontrol pergaulan anak.

a. Sekolah (guru) menerapakan metode pembelajaran Kooperatif. Selain itu guru harus memperhatikan psikologi dan sesuai dengan perkembangan multiple intelegensi anak. Jangan bertindak sebagai 'bos', dimana memberi perintah langsung bila ingin dilakukan anak dengan baik. Guru harus menerapkan mata pelajaran di sekolah yang terintegrasi dengan penanaman nilai-nilai moral dan karakter yang baik. Guru harus menjadi model yang baik dalam interaksi sosial anak.

b. Lingkungan sosial (masyarakat dan media):

1) Masyarakat harus berperan menumbuhkan norma sosial yang baik

2) Media massa harus memberikan tontonan dan tuntunan yang baik bagi anak 


\section{DAFTAR PUSTAKA}

Alex Sobur. 2003. Psikologi Umum. Bandung: Pustaka Setia.Andi Wiramihardja,S. A. 2012.

Pengantar Psikologi Klinis. Bandung: Refika Aditama.

Burt, Donnellan, Iacono, McGue. 2011. Age-of-Onset or Behavioral Sub-Types A Prospective Comparison of Two Approaches to Antisocial Behavior. Journal Abnormal Child Psychology. 3,633-644.http://neweresources.pnri.go.id/llibrary.php?id=00001.

Chaplin, J.P. 2009. Kamus Lengkap Psikologi. Alih Bahasa: Kartono., K. Jakarta: Raja Grafindo Persada.

Djaali. 2002. Psikologi Pendidikan. Jakarta: Program Pasca SarjanaUniversitas Negeri Padang.

Elida Prayitno. 2006. Psikologi Perkembangan Remaja. Padang: UNP Press.

Firman, dkk.2013. Program Bimbingan dan Konseling dalam Penanggulangan Kekerasan dan Agresifitas Remaja Siswa SMTA Kota Padang. Jurnal. Padng: FIP UNP.

Fortin, Laurier. 2003. Students Antisocial and Aggressive Behavior: Development and Prediction. Journal of Educational Administration, 41(6), 669-682. http://www.emeraldinsight.com/researchregister.

Gabbard GO, 2005, 'Cluster B Personality Disorders', in Psychodynamic Psychiatry in Clinical Practice, 4th edn, American Psychiatric Publishing Inc., USA, p.513-39.

Hurlock Elizabeth. 2001. Child development. New York: Mc. Graw Hill Book.co.inc.

Ifdil, I. (2010). Pendidikan Karakter dalam Bimbingan dan Konseling. Pedagogi: Jurnal Ilmu Pendidikan, 10(2), 55-61.

Indra Ibrahim. 2003. Peran Pengasuhan Pola Orang Tua dalam Self Esteem.Bandung: UNPAD Lier, and Vitaro. 2007. Onset of Antisocial Behavior, Affiliation with Deviant Friends, and Childhoodand Adolescent-Onset Models. Development and Psychopathology, 19, 167-185, http://neweresources.pnri.go.id/library.php?id=00001.

Mudjiran dkk. 2000. Perkembangan Peserta Didik. Padang: Dirjen.

Muhibbin Syah. 1995. Psikologi Pendidikan Suatu Pendidikan Baru. Bandung: Remaja Rosdakarya.

Mujiono dan Dimyati. 2002. Belajar dan Pembelajaran. Jakarta: Rineka Cipta

Muslimin dan Ibrahim. 2000. Pembelajaran Kooperatif. Surabaya: UNESA.

Nasution, Wahyudin Nur. Efektifitas Strategi Pembelajaran Kooperatif Dan Ekspositori Terhadap Hasil Belajar Sains Ditinjau Dari Cara Berpikir. (http://rafiud.wordpress.com/assalamualaikum/ciri/koopertif).

Nevid, Jeferry S., dkk. 2005. Psikologi Abnormal. Jakarta: Erlangga.

Reski, N., Taufik, T., \& Ifdil, I. (2017). Konsep diri dan kedisiplinan belajar siswa. Jurnal EDUCATIO: Jurnal Pendidikan Indonesia, 3(2), 85-91.

Rodkin, Farmer, Pearl, Van Acker, Herrenkohl, Huang. 2000. Heterogeneity of popural boys: Antisocial and prosocial configurations. A comparison of social development processes leading to violent behavior in late adolescencefor childhood initiators and adolescent initiators of violence. Development Psychology, 36, 14-24. http://ntalagewang.wordpress.com/2011/02/24/pembelajaran/kooperatif.

Sarwono, W. Sarlito. 2012. Pengantar Psikologi Umum. Jakarta: Rajagrafindo Persada.

Silitonga Ferry. 2010. Ganguan Kepribadian Antisosial (psikopat). http://sosbud.kompasiana.com/2010/04/04/gangguan-kepribadian-antisosial-psikopat/.

Diakses tanggal 16April 2018.

Setyawati, Tuti. 2010. Perilaku Anti Sosial. Online. http://tutisetiyawati.blogspot.com/2010/10/perilaku-anti-sosial.html. Diakses tanggal 16 April 2018.

Sobur. Alex. 2009. Psikologi Umum. Bandung: Pustaka Setia. 
Supratiknya. 2012. Mengenal Perilaku Abnormal. Yogyakarta: KANISIUS.

Schaefer dan Willman. 1981. Anak Berkebutuhan Khusus: Anti Sosial

http://kunjungisaya13.blogspot.co.id/2012/04/anak/berkemampuan/khusus/anti/sosial._ diakses tanggal 16April 2018.

Taupik Rohman, dkk. 2007. Suatu Kajian Kehidupan Masyarakat. Jakarta: Yudistira. Walgito. B. 2003. Psikologi Sosial (Suatu Pengantar). Yogyakarta: Rineka Cipta.

Wiramihardja, Sutardjo. 2007. Pengantar Psikologi Klinis. Bandung: Refika Aditama. Yusuf, Syamsu. 2004. Psikologi Perkembangan Anak dan Remaja. Bandung: Remaja Rosdakarya.

Zola, N., Ilyas, A., \& Yusri, Y. (2017). Karakteristik Anak Bungsu. Jurnal Konseling dan Pendidikan, 5(3), 109-114. 